\title{
Ocular Adnexal Lymphoma Pathologic Distant Metastasis TNM Finding v8
}

National Cancer Institute

\section{Source}

National Cancer Institute. Ocular Adnexal Lymphoma Pathologic Distant Metastasis

TNM Finding v8. NCI Thesaurus. Code C140859.

A pathologic finding about one or more characteristics of ocular adnexal lymphoma, following the rules of the TNM AJCC v8 classification system as they pertain to distant metastases. 